response requires more than treating injuries. ${ }^{3}$ Yet this does not happen partly because of "attitudes and beliefs about the 'proper' roles for men and women in relationships." These attitudes are ubiquitous and are held by the professionals who meet the victims of domestic violence. Progress will be made only when doctors not only deal with the immediate needs of victims but are also prepared to tackle the difficult task of looking for long term measures aimed at preventing domestic violence. That means identifying and then changing the conditions that give rise to it.

GILLIAN MCILWAINE

Community Medicine Specialist (Women's Health),

Glasgow Royal Maternity Hospital,

Glasgow G4 0NA

1 Department of Health. Promoting women's health. London: King's Fund, 1989. (Conference report.)
2 Commonwealth Department of Community Services and Health. National women's health policy advancing women's health in Australia. Canberra: Australian Government Publishing Service, 1989.

3 Smith LJF. Domestic violence: an overview of the literature. London: HMSO, 1989. (Home Office Research Study No 107. .

4 Freeman MDA. Violence in the home. Farnsborough: Sexon House, 1979.

5 Borkowski M, Mutch M, Walker V. Marital violence. The community response. London: Tavistock Publications, 1983.

6 Marsden D, Owen D. Jekyll and Hyde marriages. New Society 19758 May:333.

Marsden D. Sociological perspectives on family violence. In: Martin JP, ed. Violence in the family. Chichester: John Wiley, 1978

8 Harrop-Griffiths J, Kenton W, Walker E, Holm L, Russo J, Hickok L. The association between chronic pelvic pain, psychiatric diagnosis and childhood sexual abuse. Obstet Gynecol 1988;71: 589-94.

9 Dobash RE, Dobash RP. Violence against wives. New York: Free Press, 1979.

10 Schei B. Interviewing women about sexual abuse - experience from a controlled study of women in abusive relationships. In: Von Hall E, Everaerd W, eds. The free woman. Women's health in the abusive relationships. In: Von Hall E, Everaerd W, eds. The free woman.
1990s. Carnforth, Lancashire: Parthenon Publishing Group, 1989:726-33.

11 American College of Obstetricians and Gynecologists Patient Education. The abused woman. Washington, DC: ACOG, 1988

12 Centers for Disease Control. Education about adult domestic violence in US and Canadian medical schools 1987-88. FAMA 1989;261:972-8.

3 Braham R, Furniss K, Holtz H. Hospital training on domestic violence. Morriston, New Jersey: Jersey Battered Women's Service, 1986.

\title{
Training for general practice
}

\author{
No place for a national curriculum
}

Planning the education of future general practitioners has to take account of many influences. The government has called for improved undergraduate and vocational training and it is demanding some form of accountability. ${ }^{12}$ The profession wants a different form of audit ${ }^{34}$ and has new ideas on what constitutes the knowledge base of medicine generally ${ }^{5}$ and of primary care in particular. ${ }^{467}$ The European Community Commission requires that by 1995 general practitioners of all member states should have completed vocational training ${ }^{8-12}$ - and one consequence may be increased immigration from medically overcrowded neighbouring countries.

At present in Britain the quality of vocational training is very variable, as was highlighted in the furore ${ }^{1314}$ after the Joint Committee on Postgraduate Thinking in General Practice withdrew recognition of the North East Thames vocational training scheme in $1988 .{ }^{15} 16$ The content is also varied: some training puts less emphasis on chronic disease, ${ }^{17}$ management and communication skills, ${ }^{11}$ and palliative care ${ }^{18}$ than on acute conditions and specialties such as dermatology (M H Kelly, T S Murray, personal communication). Some commentators have argued that three years is not long enough for adequate training ${ }^{11}$; others seem satisfied.

In the current climate of opinion such variation is unsettling for planners. One solution that has been proposed is to agree a national curriculum, perhaps built upon The Future General Practitioner ${ }^{19}$ and the examination for the membership of the Royal College of General Practitioners, already seen by many as a test of satisfactory vocational training. Such a curriculum may be superficially attractive and seem a road to consensus, but consensus often means a compromise that suits nobody and one which may stultify the education process by the dullness of uniformity.

What young general practitioners need is teachers who know the difference between training, which fills the knowledge pot, and education, which lights the fire under it, and who will allow learners to develop the skills of communication and empathy so undervalued in present training ${ }^{20}$ and practice. $^{21}$ Young men and women are entering general practice from a wide range of backgrounds, races, cultures, medical schools, and life experience. ${ }^{22}$ Soon these differences may be swelled by imports from Europe. ${ }^{81012}$ How could a common curriculum be devised for so diverse a group of graduates?
To make sense of educating this highly disparate group we must think not of where we are trying to go but where we are starting from. Any curriculum laid down in advance might easily result in new graduates being taught what they already know while leaving many aspects of ignorance untouched. We need to test trainees before they start their vocational training, to measure the needs of entrants so that individual teaching may be offered to every trainee. General practice, with its unique opportunities for one to one teaching, is the only place where individual curricula could work: but that assumes that individual need would be accurately assessed at the outset of what may have to be a longer course. If the present rate of 25 applicants for each place increases then a pretest may also offer a useful method of selecting trainees.

Macmillan Senior Lecturer in Palliative Care,

ROBIN HULL

Department of General Practice,

University of Birmingham Medical School,

Birmingham B15 2TJ

1 Hull R. Government proposals for primary care: white hope, elephant, or sepulchre? Br Med $\mathcal{F}$ 1987;295:1436.

2 Secretaries of State for Social Services, Wales, Northern Ireland, and Scotland. Promoting better health. London: HMSO, 1987. (Cmnd 249.)

3 Pendleton D, Schofield T, Marinker M. In pursuit of quality. London: Royal College of General Practitioners, 1986.

4 Hart JT. A new kind of doctor. London: Merlin Press, 1988.

5 White KL. The task of medicine: dialogue at Wickenburg. Menlo Park, California: Henry J Kaiser Family Foundation, 1986

6 Stott NCH. Primary health care. Berlin: Springer Verlag, 1983.

7 Hull FM. The role of socio-behavioural scientists in health care practice. Soc Sci Med 1987;25: 679-87.

8 Hull R. Training for general practice in Europe. Horizons 1989;3:212-20.

9 Anor ymous. Assessment of vocational training [Editorial]. Fam Pract 1988;5:1-3.

10 Rombauts WAJA. A European perspective on postgraduate education. Biochem Soc Trans 1988;16:122-5.

11 Hasler JC. History of vocational training for general practice: the 1970s and 1980s. $\mathcal{F}$ R Coll Gen Pract 1989;39:338-41.

12 Horder J. Vocational training for general practice in the European community. $7 R$ Coll Gen Pract 1988;38:341-2.

13 Campkin N, Grant $\mathrm{D}$, Suckling $\mathrm{H}$. Withdrawing recognition for vocational training. $\mathrm{Br} \mathrm{Med} \mathcal{f}$ $1988 ; 296: 1331$

14 Josse SE. Vocational training in general practice. $\operatorname{Br} M e d f$ 1988;297:134

15 Lowry $S$. Vocational training in general practice: is action against north east Thames justified? BrMed f 1988;296:1320.

16 Anonymous. College action in the north east Thames region. $f$ R Coll Gen Pract 1988;38:239.

17 Hasler JC. Do trainees see patients with chronic illness? Br Med f 1983;287:1679-82.

18 Richards CM. The teaching of terminal care and care of the bereaved in vocational training schemes. RCGP/Schering scholarship report. London: Royal College of General Practitioners, 1987.

19 Royal College of General Practitioners Working Party. The future general practitioner. Learning and teaching. London: British Medical Journal, 1972.

20 Pickering G. Quest for excellence in medical education. London: Nuffield Provincial Hospital Trust, 1978.

21 Shorter E. Bedside manners, the troubled history of doctors and patients. New York: Simon and Schuster, 1985.

22 Payer L. Medicine and culture. London: Gollancz, 1989. 